\title{
Biography in Pedagogical Activity: Theory and Practice
}

\author{
Yakovleva S.V. \\ Pskov state University \\ Pskov, Russia \\ atevsa@inbox.ru
}

\begin{abstract}
Multidimensionality, inconsistence, constant mobility of modern socio humanistic situation, blurring of lines (cultural, ethical, aesthetical, religious), loss of focuses, fast changes of every area of life, changes of relations between people, changes of many norms and principles of human activity require new approaches to the analysis of people development and education opportunities optimization.

Importance of biography study is based on social conflicts between society demand for active, self-fulfilled pupil and its insufficient readiness to it, objective need of all people to the building and actualization of an individual biography and minimized development of the methodological and methodical basis of biography material' usage in educational process, between conflicts in pedagogical theory and praxis such as realization of the fact that biography is an important information source about the individual and unique pupil's life and full oa particular ignoration of this information, understanding that biography is a history of student's becoming which presents axiological bases of its life and often episodical, spontaneous, casual interest to the student's life.

The article gives the analysis of learned treatise in order to give theoretical foundation of biography as a pedagogical phenomenon. Theoretical importance of the article is the developing of theoretical basis of biography as pedagogical phenomenon, analysis of features and functions of biography in the pedagogical process. Practical significance is to see in the developing of conditions which permit to use the biography in the modern educational practice and to get a qualitatively new educational result. The problem of purposeful use of biography in pedagogical activity is investigated. The possibility of constructing a modern process of education (educational process) on the basis of the pupil biographical material is considered.
\end{abstract}

Keywords - biography as a source and content of the education process, as a means of the pedagogical process subjects pedagogical interaction; pedagogy of being, philosophical, and anthropological approach; the purpose of education as a person 'equal' to himself.

\section{INTRODUCTION}

In modern conditions of digitalization of various spheres of society life and individual increase of living space informatization, prevalence of interactive virtual communication over real, immersion and "dissolution" of the person in a boundless information stream and coercion to act according to any given scenario (Yu. Habermas). It is important to address the problem of biography as a source and determinant of human development and biographical competence as an ability of conscious realization of one's unique biographical path. Not to turn into "digits", not losing their own identity, to preserve the meaning of existence in the process of integration into the global multicultural community, it is necessary to remember that, despite the introduction of innovations in the pedagogical process, it primarily is due to the anthropological nature and should be aimed at acquiring by its participants the skills of interpretation, evaluation, construction of his biographical itinerary, as he has a total character, pervading all spheres and aspects of each person life.

\section{LITERATURE REVIEW}

Biography-quite intensively used in modern science and literature concept. In foreign pedagogical science the attention to the biography of the person as a pedagogical problem first drew $\mathrm{Yu}$ Henningsen. According to the scientist, autobiography can act as a "historical source for pedagogical research", because it "captures what was important for a contemporary from the point of view of education: the images of the teachers, books, events and meetings with people and their teaching role" [6, p.11]. In other words, autobiography is a subjective assessment of the importance in the life of an individual of certain events, people. Who, what, why and what has influenced life-this is their "learning role". A variety of events and life experiences are material for education when taken into account in the perspective of a lifetime. The life of the individual appears as a " personalized version of education "(Y. Henningsen).

Pedagogical anthropology studies the problem of childhood as a self-valuable period in a person's life and memories of childhood as a way of its reconstruction. "Let not all stored in consciousness and subconsciousness the autobiography fixes, but that it finds out, cannot be neither casual, nor insignificant",-B. M. BIM-bad asserts [5, p. 4]. The autobiography of childhood is very subjective, however, according to researchers, it is important to know how the child himself evaluates the facts of his life, what he considers essential, what is secondary, because this is decisive for the construction of the child's future.

An interesting study is the work of V. V. Nurkova devoted to autobiographical memory, which, according to the author, gives a person the material to create the history of his life and the concept of fate $[4$, p. 67-68]. 
Recently, biographical work has become widespread in Western countries in working with children and adolescents, with women, with people with disabilities, the elderly, etc.and has undeniable prospects $[10,11]$.

The modern teacher should understand that at the moment of meeting with the pupil he does not represent a "blank slate", but already has a certain experience of relations with the world, with people, with himself, i.e. he has a very special, unique history of his own formation. It is obvious that the activities of the teacher cannot be limited to the study of pupils "personal affairs". The idea that the kid meets the teacher, already has his biography, which is not only events, but experiences of life, facts that have received a rating and become the experience becomes the basis of defining the content, the nature of interaction between teacher and pupil and the result of the education process.

In our understanding biography is a process and result of the person biographical development which is shown in an assessment and comprehension by it of separate biographical episodes consisting in understanding of own destiny and forecasting and creative, conscious realization of the unique biographical route $[7$, p. 81$]$.

Understanding of biography as a set of feelings, experiences, impressions, their assessments and its significance for the further admission of the pupil is based on the ideas of the pedagogical human studies Creator G. Zero, who formulated the laws of human existence, one of which is called the law of the spiritual process structure [3, p. 85-87]. This law emphasizes the importance of life impressions, from the way of processing, evaluation of which, identification and expression in behavior depends on the formation of spiritual activity types. The history of individual life, according to Zero, exists in human memories as a distinctive organ of selfunderstanding and understanding of the world. Memory is a kind of organ that is obliged to remember what a person has done and what he could not make of himself, who he became in life and who he would like to become. The formation of this structure due to the "categorical project of being" the man who reflects man's relation to the other events of the past and present and contributes to the realization of the human desire for self-realization, development "proper" in accordance with their capabilities.

\section{RESEARCH METHODOLOGY}

This understanding of the education process and the importance in this biography of the individual pupil asks a philosophical-anthropological approach, according to which man is "always becoming, the being" (M. Scheler), "being not specified at all times" (O. F. Bollnow), "being plastic, ready to deploy their skills, improve their abilities, with a desire to be better, more perfect" (G. Zero) [2, p. 85, 87], goal nourishing help child become themselves, choose themselves and its the true path in life, task pedagogue-try to understand the only, only pupil belonging to vital path, which is leading him to perfection, the most full self-realization and help him in this, for in real life man not always adequate to his purpose, living sometimes "someone else's" life, and own
Biography in this context is the basis, the content of the education process, the immanent aspects of which are the whole themes of life, priority lines of reflection on a number of existential concepts (choice, love, happiness, responsibility, freedom, good, evil, etc.) and categories of being (man, life, meaning of life, purpose of life, human destiny, selfdetermination, self-education, etc.), contemplation, motives, actions, etc., the basis and result of which is the "biographical competence" of its subjects. This concept was introduced by V. Lohom, who defined this term as an invariant series of abilities and associated motives that each person can develop on the basis of his universal ability, the specific abilities of a person when biographical situations and put the pupil specific educational tasks.

\section{RESULTS}

Human biography is a dynamic phenomenon, a set of biographical choices. Biography appears as a static phenomenon, a stable state of the subject, associated with the realization and implementation, or at least approaching their own vocation, with the determination of their place in the world, the acquisition of a stable system of values, positions, meanings. "The sum of events, elections and decisions is our life", - noted Y. Henningsen [8, p. 93]. A person builds a biography both in specific situations and in the course of his whole life. It is a one-time act and a continuous, long, holistic process.

The unique possibilities and meanings of the biography use in the modern practice of education help to open the latest research in the field of axiology, synergetics, psychology. Thus, from the point of view of synergetics, a person is considered as a complex self-organizing and self-developing system, the formation and development of which is a multivariate, nonlinear and irreversible process. The biography of the person can be represented as a series of choice points: the exhaustion of a particular life stage and transition in non-equilibrium state - a state of formation and define new meanings and ways of living - makes him need to select one of the alternatives for further development, what happens at bifurcation points. From the standpoint of synergetics, even very weak information effects on a person who is in the bifurcation zone (in a situation of choice) can become decisive for the choice of the trajectory of further development.

Biography has both activity, reflexive and value-semantic character. The choice or action in a particular situation involves not only the action, but also the attitude to various aspects of reality. The biography of each person has a culturelike character, since the biographical choice is correlated with the values and norms of culture, and cultural-creative character, which emphasizes the ability of a person to meaningful transformation, independent discovery of new values and meanings of his own life. The task of the teacher in this context is to present a rich palette of values and meanings, to create conditions for free choice, involving pupils in dialogues about the meaning of life and destiny

In human biography it is possible to distinguish such interrelated components: 


\section{CONCLUSION}

Pedagogical activity in the considered context consists in "strengthening and awakening the ability of the individual to self-understanding, to subjectively meaningful, personally satisfied and socially productive self-realization in his life path" [9, p. 243], because " personality ... it is the most important determinant of its own. Each personality is partly its own project and creates itself" [3, p. 243]

The task of the teacher with the indicated approach is to create a space where the pupil "exists", lives not invented, but real life, to help the child become himself, to choose himself and his true path in life, which leads him to perfection, the most complete self-realization and to help him in this. The pedagogical process must ensure that the pupil of the objective and subjective opportunity for self-realization, the opportunity to "choose" in accordance with "personalized" understanding of the life and vocation meaning, for "every man's life is the way to yourself, attempt the way, a hint on the trail. No man has ever been entirely himself; yet each strives for it, some in a dull, some in a distinct way, each as best he can..., each, being an attempt, being a throw from the abyss, rushes to its own goal" [1, p. 40]

\section{References} important topics and to design his biography. The formation of the "categorical project of being" is taking place Y.Holl), which reflects the attitude of a person to certain events of the past and present and contributes to the realization of his desire for self-realization, the formation of a person "due" in accordance with their capabilities [5, p. 170-176];

- the value-semantic function is realized in the fact that in the biographies of other people the pupil comprehends the values and meanings that determine life choices and actions. There is a "dialogue of meanings" (M. M. Bakhtin) [1], the biographical choices of the participants of which appear as a "sample of value choice". The task of the teacher is to try to understand the only way of life belonging to the pupil, which leads him to the most complete self-realization, and to help him in this, because in real life a person is not always adequate to his destiny, sometimes living "someone else's" life, and his own choices in life often, unfortunately, remain In our opinion, the purpose of education must be correlated with the ultimate question of human existence, which J. P. Sartre described as "a very personal question about the 'main thing', namely, what exactly are we doing here and now and what is the point of it?»;

- the design function of biography is reflected in the desire of the individual to predict and design the life path. The pupil correlates biographies with events, facts of his life. The pedagogical task is to organize the processes of constructing a biography.
1] Hesse G. Demian. History of youth, written by Emil Sinclair. Foreign literature. 1993, 5, pp. 40.

[2] Kulikov B. V. Pedagogical anthropology. Sverdlovsk. 1988.

[3] Livehood B. the Crises of life - the chances of life. Human development between childhood and old age. Kaluga. 1994.

[4] Nurkova V. V. the Accomplished state: psychology of autobiographical memory of the person. Moscow. 2000.

[5] The nature of the child in the mirror of autobiography: A textbook on pedagogical anthropology. 1998.

[6] Henningsen Y. Autobiography and pedagogy. Moscow: publishing house urao. 2000.

[7] Yakovlev S. V. Biography of the man problem in the field of modern education. Proceedings of Volgograd state pedagogical University. 2010, 9(53), pp. 80-83. Geschichte. Juventa. Weinheim und München. 2011.

[9] Loch W. Curriculare Kompetenz und pädagogische Paradigmen. Zur anthropologischen Grundlegung einer biographischen Erziehungstheorie. In: Bildung und Erziehung. 1979, 32.

[10] Alexsandr S. Kuznetsov. Russian Professor's meeting. Russian Journal of Physical Education and Sport. 2019, 14(1), pp. 17-22. DOI: 10.14526/2070-4798-2019-14-1-18-24

[11] Ruhe H. Methoden der Biografiearbeit. Lebensspuren entdecken und verstehen. Juventa. Weinheim und München. 2007.
[8] Lattschar B., Wiemann I. Mädchen und Jungen entdecken ihre 